\title{
СТРАТИГРАФИЯ БАЙОС-БАТСКИХ МОРСКИХ ОТЛОЖЕНИЙ НИЖНЕГО ПОВОЛЖЬЯ
}

\section{В.Ф. Салтыков, Г.Н. Старцева, Е.А. Троицкая}

Саратовский государственный университет, лаборатория петрофизики

E-mail: dekanat@geol.sgu.ru

В принятой недавно региональной стратиграфической схеме средней юры для Саратовско-Волгоградского Правобережья имеются неопределённости по границам, объёмам и возрасту местных стратонов. На основе анализа новых фактических материалов, полученных при изучении керна многочисленных скважин и при обследовании обнажений в стратотипической местности на севере Волгоградской области, производятся необходимые уточнения. Для подразделений приводятся литологические и палеонтологические характеристики, описываются контактовые зоны между ними, оцениваются их мощности и ареалы на территории Нижнего Поволжья.

Ключевые слова: байос-бат, морские отложения, СаратовскоВолгоградское Правобережье, стратиграфия, уточнения.

\section{Stratigraphy of the Baojcian-Bathonian Marine Deposites of the Volga Region}

\section{V.F.Saltykov, G.N.Startseva, E.A.Troitskaya}

There are unceptainties in the boundaries, extensions and ages of the suites recognized in the recent regional stratigra-phic chart for the Middle Jurassic of the Saratov and Volgograd Volga right-bank Regions. Analyses of the new factual materials acquired from numerous well cores and the data from the outcrops in the stratotype locality at the North Vol-gograg Region make the basis for elaborating the deposite division. Detaled lithologic and paleontologic characteristics, their thicknesses and areals are estimated over Volga right-bank Region.

Key words: bajocian-bathonian, marine deposits, Saratov-Volgograd Volga-river Right bank, stratigraphy, detalization.

\section{Введение}

Среднеюрские морские отложения покрывают большие пространства Нижнего Поволжья. Чаще всего они погружены на большие глубины, но на приподнятых участках Доно-Медведицких и Саратовских дислокаций они обнажены в ряде оврагов, где составляют стратотипические разрезы. Долгое время значительная протяженность разреза относилась к байосу и лишь его верхняя часть датировалась батом $[1,2]$. Однако палеонтологическая обоснованность такого датирования была явно недостаточной как с точки зрения количества и разнообразия собранной фауны, так и в отношении систематического изучения её основной группы - аммонитов и установления их стратиграфического положения. Имевшиеся данные по фораминиферам выполняли вспомогательную роль, хотя они были более многочисленными [3-5]. Е.А. Троицкая и Т.Н. Хабарова предложили другое деление байос-батских отложений региона, согласно которому их основная часть отнесена к нижнему бату [6]. Во всех случаях к северу от широты Камышина эти образования рассматривались в качестве единого стратона, хотя вертикальное распределение фораминифер явно показывало их разделение на два самостоятельных подразделения, что получило свое отражение в сводке [7]. Применённый в 1990-е годы свитный принцип расчленения пород породил новые неопределённости в соподчинённости свит и их возрасте, выделенных на основании существовавших представлений по биостратиграфии байос-батского диапазона [8-10].

В то же время выполненные в последние годы исследования по систематике позднебайосских и раннебатских аммонитов [11-13], включая и результаты ранних работ $[14,15]$, обосновали необходимость пересмотра существующей аммонитовой шкалы верхнего байоса и нижнего бата применительно к площади юго-востока Русской платформы и приведения её в соответствие с обновлённым аммонитовым стандартом Западной Европы [16].

Разнообразные литологические и палеонтологические материалы, собранные при производстве геологосъёмочных работ масштаба 1 : 50000 на территории северной оконечности Доно-Медведицких дислокаций, где расположены стратотипические разрезы рассматриваемых отложений [8], служат фактологическим обоснованием обновления стратиграфической схемы для региона. Важно отметить, что в многочисленных скважинах и более редких обнажениях (рис. 1) образцы с аммонитами сопрягались с образцами с фораминиферами и другой фауной. Выход керна находился в пределах 65-75\%. В результате анализа этих подробных сведений удалось составить полные литологические и палеонтологические характеристики свит, дать описание контактовых зон между ними и уточнить их стратиграфическое положение. Следует заметить, что последнее сближается с представлениями В.В. Митты $[12,13]$.

В статье [8] рассматриваются бахтемирская, караулинская, жирновская и каменноовражная свиты. Анализ их стратиграфической изученности с критикой положения в разрезе изложен в статьях $[17,18]$. Помимо собственных сведений используются данные В.И. Левиной и Н.П. Прохоровой по бахтемирской свите, А.И. Сарычевой [5] и неопубликованные материалы Е.А. Троицкой по 


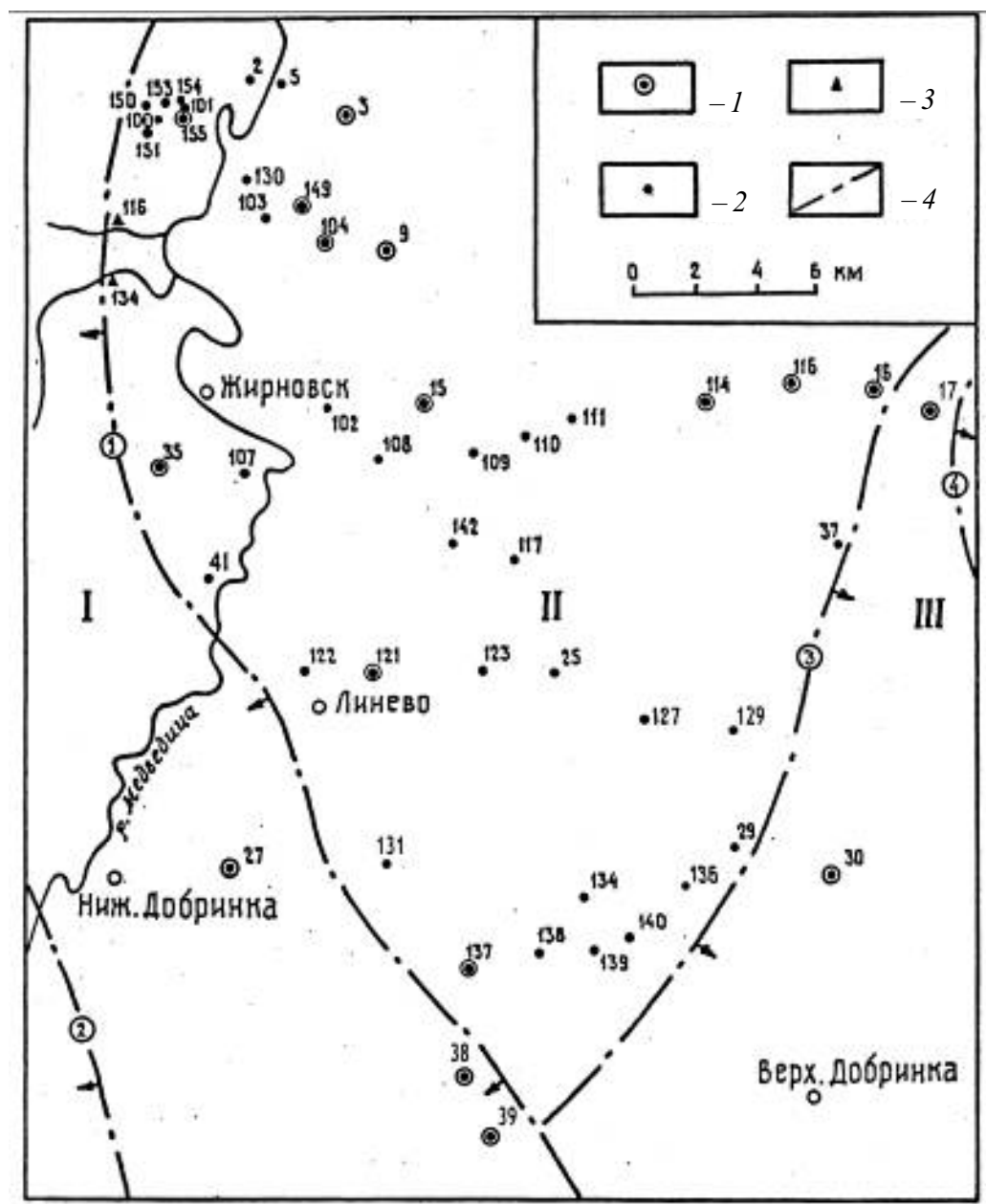

Рис. 1. Расположение скважин и ключевых обнажений на севере Волгоградской области, вскрывших байос-батские отложения: 1 - опорные скважины; 2 - дополнительные скважины; 3 - обнажения; 4 - флексуры в мезозое над тектоническими нарушениями в палеозое; стрелками показано направление падения сместителей (цифры в кружках): 1 - Западно-Жирновская; 2 - Лемешкинская; 3 - Синегорская; 4 - Восточная; тектонические структуры: I - Терсинская впадина; II - Жирновско-Иловлинский вал; III - Приволжская моноклиналь

распределению аммонитов в некоторых ключевых обнажениях.

Бахтемирская свита $\mathbf{J}_{\mathbf{2}} \mathbf{b h}$ представляет самые древние морские отложения, достоверно установленные в Поволжье, соответствующие аммонитовой зоне Garantiana garantiana верхнего байоса стандарта. В качестве типового разреза принят интервал 1544-1733 м в скв. 3 Полдневской (50 км к югу от Астрахани) [8]. Выделены две пачки: нижняя сложена переслаивающимися алевролитами, глинами и песчаниками с растительными остатками мощностью до 100 м без присутствия фауны; верхняя представлена аргиллитоподобными глинами с прослоями алевритов и тонкозернистых песчаников мощностью до 100 м. В них найдены зональные аммониты G. garantiana (Orb.) и фораминиферы Lenticulina polynorpha (Terq.), Garantella caucasica Ant., G. asterigerinoides Kapt., G. stellata Kapt. и др., обнаруженные в единичном образце из верхов разреза. Также кратко описан байосский палинокомплекс. Свита залегает или непосредственно на палеозойских породах, или на так называемой «гнилушкинской свите», литологический состав которой сходен с таковым в нижней пачке бахтемирской свиты. В.И. Левина и Н.П. Прохорова отмечают её выклинивание на широте Камышина.

По поводу стратиграфического положения указанной свиты не имеется существенных возражений, так как её датировка обоснована находками аммонитов и фораминифер. Но предлагаемые вещественный состав и объём являются спорными. Более детальные микрофаунистические данные приводились А.И. Сарычевой $[5,19]$, которая сопоставила разрезы по ряду скважин в Волгоградской и Астраханской областях, причём на Паромненской площади (около Волгограда) в глинах был обнаружен зональный ам- 
монит и отобраны многочисленные образцы, содержащие характерный фораминиферовый комплекс. Эти глины покрываются глинами и алевритами с присутствием вида Ammodiscus subjurassicus Sar. et Chab., свойственного для верхнего байоса [20]. Эти материалы обобщил А.В. Смирнов [21], построив литолого-фациальную карту байосского яруса. Он отметил, что мощность отложений, позднее отнесённых к бахтемирской свите, убывает от 75 м на юге до полного выклинивания на севере (на широте Камышина).

Таким образом, принадлежность верхней глинистой пачки к самостоятельному подразделению, но с несколько меньшими мощностями (порядка 100 м), чем считали В.И. Левина и Н.П. Прохорова, не вызывает сомнений. Но отнесение её к зоне G. garantiana является недостаточным. Несмотря на малочисленность находок аммонитов, обнаружение этого вида даёт основание предполагать его расположение только в нижней половине аммонитовой зоны стандарта - в подзонах dichotoma и subgaranti [16]. Принятие такого возраста увеличивает амплитуды перерыва седиментации между кровлей бахтемирской и подошвой караулинской свит; последняя относится к верхней части аммонитовой зоны Parkinsonia parkinsoni стандарта [12].

Отсутствие убедительного фаунистического обеспечения для нижней пачки бахтемирской свиты, по мнению В.И. Левиной и Н.П. Прохоровой, ставит вопрос о правомерности её включения в состав этого стратона. Ранее А.В. Смирнов [21] песчано-алевритовые отложения мощностью до 40 м, подстилающие глины с $G$. garantiana (Orb.), датировал более древним возрастом в пределах байоса. А.И. Сарычева [19] считала их аналогом слоев с Strenoceras niortense (Orb.), венчающих нижележащую аммонитовую зону niortense верхнего байоса стандарта [16]. При этом она указывала на чёткое отделение этих пород от вышележащих глин, что было продемонстрировано на изученных каротажных диаграммах. А.В. Смирнов и А.И. Сарычева полагали, что эти отложения характеризуют прибрежно-лагунные условия осадконакопления в отличие от типично морских образований глинистой пачки бахтемирской свиты. Этот вопрос подробно рассмотрен в статье [22]. Используя данные А.И. Сарычевой $[5,19]$, можно отнести данные отложения к родионовской свите $\mathrm{J}_{2} \mathrm{rd}$ прибрежно-лагунного происхождения. Состав микрофауны, очевидно, аналогичен бахтемирскому. Их мощность составляет 32 м. В качестве стратотипического разреза можно принять интервал 1190-1222 м в скв. 3 Паромненской площади. Ареал свиты ограничен югом Волгоградского Правобережья и Астраханской областью. Подобные образования вскрыты в скважинах 4 Восточно-Можарской (интервал 2160-2245 м) и в скважине 3 Полдневской (интервал $1630-1733$ м) [8].
Следовательно, объём бахтемирской свиты можно свести к верхней глинистой пачке, по [8], и она должна соответствовать низам зоны G. garantiana - двум нижним подзонам стандарта dichotoma и subgaranti. Нижнюю песчано-алевритовую пачку следует выделять в родионовскую свиту прибрежно-лагунной фации, соотнесённую с аммонитовой зоной niortense стандарта, а не рассматривать в составе «гнилушкинской свиты», которая на юге региона отсутствует [22]. Тогда песчано-алевритовые типично континентальные отложения светлоярской свиты имеют более древний возраст, вероятно, аален-раннебайосский, чему не противоречат спорово-пыльцевые данные, но требуется её подробное описание. Они обнажаются в ряде оврагов на Донской Луке. Такой подход подчёркивается тем обстоятельством, что на границе аален-ранний байос происходила перестройка структурного плана, убедительно показанная Д.И. Пановым с коллегами [23].

Караулинская свита $\mathbf{J}_{2} \mathbf{k r l}$ выделена в ранге «серии» А.Н. Мазаровичем [24] с типовым разрезом в Караулинском овраге (бассейн Иловли), в котором преобладали песчаные глины с прослоями песков и алевритов, залегающие на континентальных гнилушкинских породах. В кровле наблюдались известняки с текстурой конус в конус. Он считал, что эти отложения являются прибрежной фацией по отношению к вышележащим байосским образованиям (в настоящее время они принадлежат к жирновской свите).

В песчаных разновидностях А.Н. Мазарович не обнаружил фаунистических остатков, но в глинах П.К. Мурашкиным [14] были описаны аммониты рода Parkinsonia, а также вид Pseudocosmoceras michalskii (Bor.). Последний по аналогии с Донбассом предварительно был отнесён к раннему бату, хотя не исключался и поздний байос. Позднее здесь, а также в разрезах Каменных оврагов (вблизи Жирновска) В.П. Николаева [15] обнаружила те же виды аммонитов. При этом она уточнила объём рода Pseudocosmoceras и выделила новый род Medvediceras, которые она считала раннебатскими. Такой подход сохранился до сих пор [8-10]. Новейшие исследования показали, что целесообразнее датировать эти аммониты только поздним байосом с частичным захватом раннего бата [11-13]. Следует заметить, что указанные аммониты отсутствуют в западно-европейских разрезах [16]. Это создаёт трудности корреляции со стандартом, не разрешённые до настоящего времени, так как рода Pseudocosmoceras и Medvediceras распространены главным образом на юго-востоке и юге Русской платформы [25].

По фораминиферам картина более чёткая. А.И. Сарычева была первой, кто фораминиферовую зону Am. subjurassicus сопоставила с караулинской свитой А.Н. Мазаровича. Такое мнение принято всеми исследователями, хотя и с некоторыми оговорками [7], и зафиксировано в современной стратиграфической схеме [8-10], несмотря 
на возникающее противоречие с положением аммонитов, датированных ранним батом. Данный вопрос подробно рассмотрен в статье [17].

Новые фактические материалы, в том числе и совместное нахождение аммонитов и фораминифер в одних и тех же образцах, отобранных из керна скважин, расположенных в стратотипической местности, позволили разрешить указанную проблему [26]. Строение караулинских отложений иллюстрирует рис. 2, на котором демонстрируются профили по скважинам, расположенным в северной, срединной и южной частях изученной площади. Впервые установлено, что во всех разрезах свита представлена двумя пачками: в низах наблюдается чередование глинистых песков, алевритов и алевритовых глин без чёткой выраженности границ между ними с общей мощностью 3-9 м; верхняя пачка сложена алевритовыми и алевритистыми глинами мощностью 6-13 м. Средние гранулометрические спектры пород приведены в табл. 1. Граница между пачками является условной. Характерно присутствие линзовидных конкреций известняков. При этом в подошве нижней пачки они интенсивно сидеритизированы. Внутри обеих пачек они обладают массивной текстурой без сидерита, а на границе с жирновской свитой известняки имеют текстуру конус в конус, нигде более не встречающуюся по разрезу. Впервые подобные породы отмечались А.Н. Мазаровичем именно в такой геологической позиции. Подробно минеральный состав конкреций и условия их возникновения рассмотрены в статье [27].
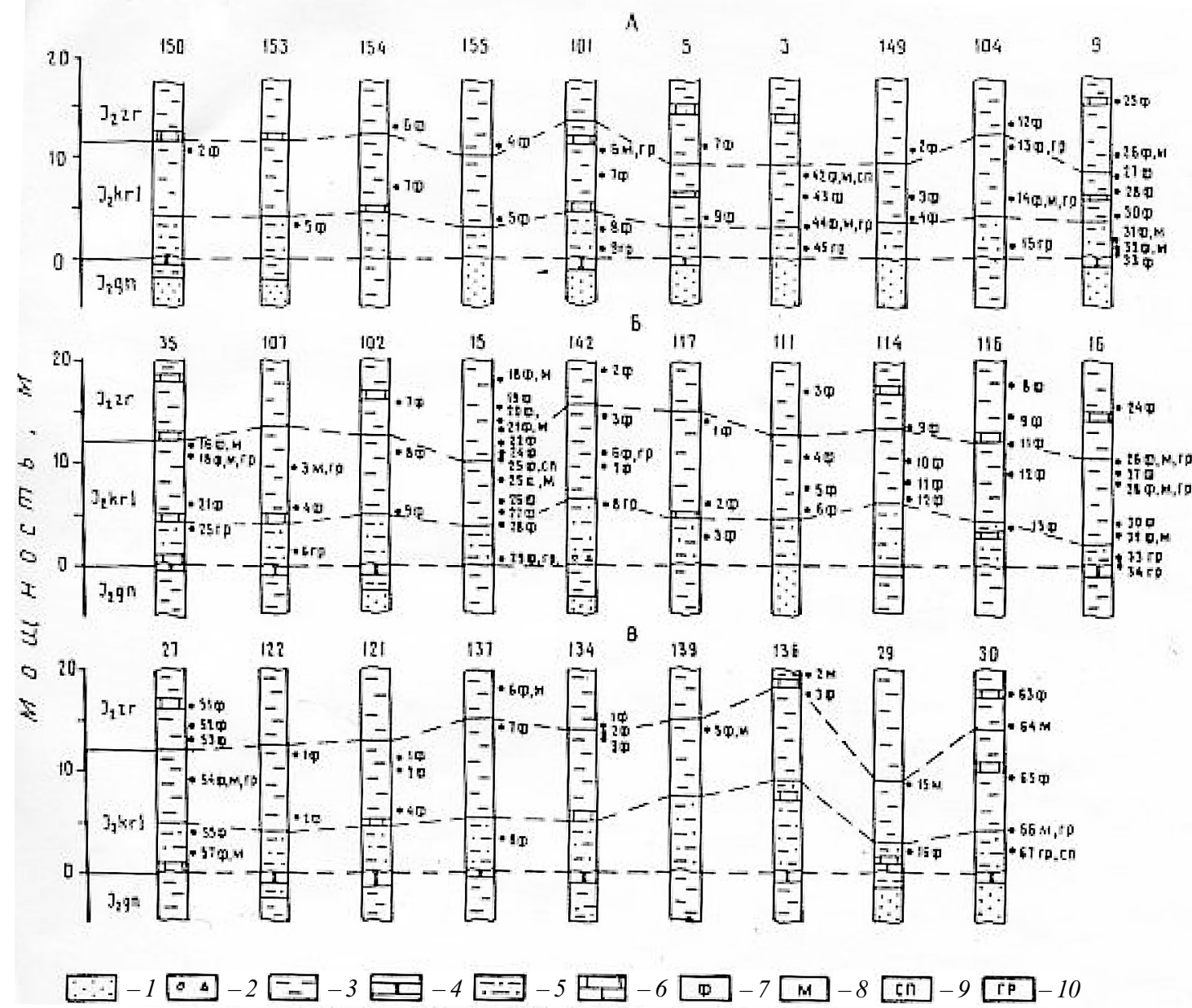

Рис. 2. Корреляция литологического состава и расположение палеонтологически охарактеризованных образцов по разрезу караулинской свиты на севере Волгоградской области; каждый ряд в целом соответствует северному (А), срединному (Б) и южному (В) расположению скважин: 1 - пески; 2 - галька и щебень; 3 - глины; 4 - песчаники; 5 - алевриты; 6 - известняки; виды опробования: 7 - макрофауна; 8 - микрофауна; 9 - спорово-пыльцевые спектры; 10 - гранулометрия; свиты: J $2 \mathrm{zr}$ - жирновская; J $2 \mathrm{krl}$ - караулинская (расположение скважин см. рис. 1)

На севере Волгоградской области (до широты Камышина) караулинская свита залегает на гнилушкинских отложениях [22], но на юге она располагается с размывом бахтемирской свиты, причём здесь её мощность возрастает до 40 м [21]. В Саратовской области отложения непосредственно залегают на палеозойских карбонатных породах. В основании наблюдаются или алевриты 
Средние гранулометрические спектры, \%, пород караулинской, жирновской и каменноовражной свит

\begin{tabular}{|c|c|c|c|c|c|c|c|}
\hline \multirow{2}{*}{ Породы } & \multicolumn{7}{|c|}{ Ф р а к ц и и, мм } \\
\hline & $>2$ & $2-1$ & $1-0,5$ & $0,5-0,25$ & $0,25-0,1$ & $0,1-0,01$ & $<0,01$ \\
\hline Глины алевритовые $\mathrm{J}_{2} \mathrm{ko}(1)$ & - & 1,0 & 0,4 & - & 0,9 & 37,0 & 60,7 \\
\hline Глины J2ko (10) & - & 0,1 & 0,8 & 0,1 & 0,9 & 5,6 & 92,5 \\
\hline Глины $\mathrm{J}_{2} \mathrm{zr}(20)$ & - & 0,3 & 0,6 & 0,1 & 1,0 & 7,6 & 90,4 \\
\hline Глины алевритовые $\mathrm{J}_{2} \mathrm{zr}$ (2) & - & 7,2 & 1,9 & 0,3 & 6,1 & 30,5 & 54,0 \\
\hline Глины аргиллитоподобные $\mathrm{J}_{2}$ krl (7) & - & 0,1 & 0,3 & 0,1 & 0,6 & 3,5 & 95,4 \\
\hline Глины алевритистые $\mathrm{J}_{2} \mathrm{krl}$ (5) & 0,3 & 0,2 & 0,2 & - & 0,2 & 15,6 & 83,5 \\
\hline Глины алевритовые $\mathrm{J}_{2} \mathrm{krl}$ (7) & 0,4 & 0,7 & 1,0 & 0,1 & 7,1 & 31,3 & 59,4 \\
\hline Алевриты $\mathrm{J}_{2} \mathrm{krl}(5)$ & 0,2 & 0,2 & 0,4 & 0,2 & 14,3 & 36,4 & 48,3 \\
\hline Пески глинистые $\mathrm{J}_{2} \mathrm{krl}$ (3) & 0,8 & 5,6 & 5,5 & 0,1 & 33,1 & 15,6 & 39,3 \\
\hline
\end{tabular}

Примечание. Прочерк означает отсутствие данного параметра; в скобках указано количество проб.

с обилием мелкого неопределимого детрита раковин двустворчатых и головоногих моллюсков и реже ростров белемнитов; или косослоистые алевропесчаники мощностью до 1 м, иногда вмещающие гнёзда тёмно-серых углистых глин, углей и песков «гнилушкинской свиты»; или конкреции сидеритизированных известняков, установленных во многих (но не во всех) скважинах. Верхняя граница в литологическом отношении выражена нечётко, но в подошве жирновской свиты глины содержат значительную примесь алевритового компонента (см. табл. 1), а также присутствуют часто наблюдаемые конкреции известняков с текстурой конус в конус.

На протяжении разреза караулинских отложений фиксируется постепенное нарастание концентраций глинистых фракций за счёт снижения содержаний алевритовой и тем более песчаных фракций (см. табл. 1). Эти данные дают возможность выделения литологических пачек при детальном опробовании. Они характеризуют медленное углубление морского бассейна седиментации, когда в верхах разреза отлагался главным образом глинистый материал. Это показывает трудности проведения границ без подробного изучения керна скважин, так как на каротажных диаграммах такие тонкости не всегда надёжно интерпретируются.

Рассмотренные отложения вмещают многочисленные и разнообразные органические остатки: обнаружены 86 отпечатков аммонитов, часты раковины двустворчатых и брюхоногих моллюсков, реже встречаются ростры белемнитов, постоянно присутствуют фораминиферы и остракоды, установлены палинокомплексы. Распределение образцов показано на рис. 2, а отдельных видов аммонитов - на рис. 3. Следует отметить, что в одних образцах встречено по 2-3 экземпляра одного и того же вида последних фоссилий, в других же отмечается присутствие 2-3 различных видов. Большинство находок приходится на гли- нистую пачку, но в алевритах ряда скважин также были обнаружены раковины такого характерного аммонита, как Ps. michalskii (Bor.) и виды-индексы фораминифер. Раковины аммонитов чаще имеют размеры от 50 до 80 мм.

Преобладающее количество (около трети) остатков аммонитов приходится на вид Ps. michalskii (Bor.), причём его распространение не выходит за пределы караулинской свиты, т.е. этот вид не обнаружен ни в одном из образцов, отобранных из вышележащей жирновской свиты. Значительно меньше находок Medvediceras aff. inclarum Mur., Med. conjungens Mur. и Rarecostites aff. mutabilis (Nic.), которые также встречены только в караулинской свите. Следующие четыре формы $P s$. minor Mur., Med. masarowici Mur., Ps. medium Mur. и Gonolkites validus Wetz. являются транзитными, и они зафиксированы и в нижних 10 м разреза жирновской свиты. При этом первые два вида наиболее обильны в караулинских глинах (19 и $35 \%$ соответственно, табл. 2). В табл. 2 показаны впечатляющие различия в составе и количестве аммонитов, установленных в обеих свитах. Аналогичная картина распределения тех же самых видов наблюдается в обнажениях Каменных оврагов. Учитывая определяющую роль вида $G$. convergens (Buck.) в разделении подразделений байоса и бата как в аммонитовом стандарте [16], так и на территории Русской платформы [11-13], эти данные убедительно доказывают обособленность караулинской и жирновской свит [26].

По поводу распределения двустворчатых и брюхоногих моллюсков в указанном подразделении в литературе приводится мало сведений, отмечается лишь частое присутствие двух видов - Meleagrinella doneziana (Bor.) и M. echinata (Smith.), причём количественная сторона их развития по разрезу обычно не оценивалась. Важным обстоятельством обнаружения этой фауны в кернах скважин является совместное их присутствие с аммонитами. Анализ её вертикального 


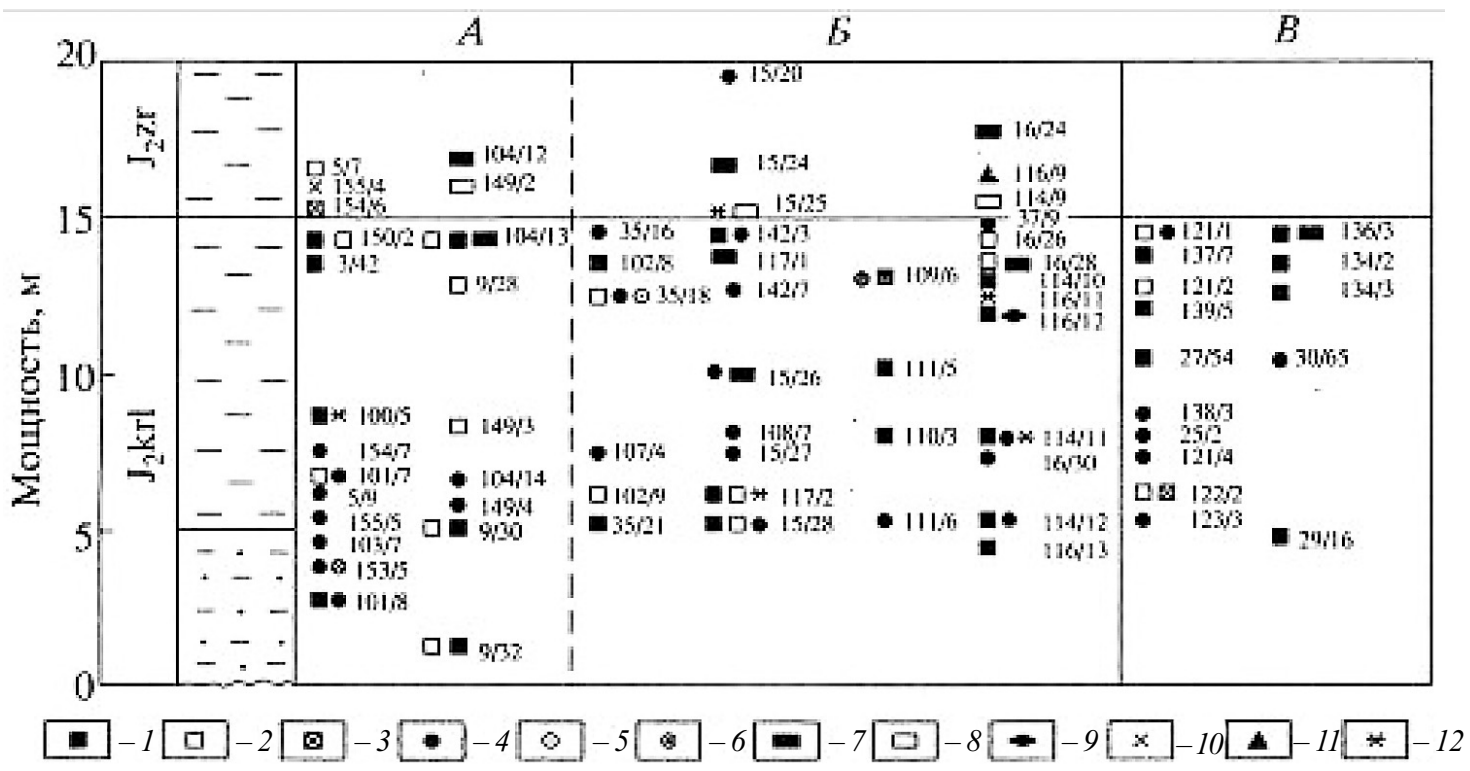

Рис. 3. Распределение видов аммонитов по усредненному разрезу караулинской свиты на севере Волгоградской области: 1 - Pseudocosmoceras michalskii (Bor.); 2 - Ps. minor Mur.; 3 - Ps. medium Mur.; 4 - Medvediceras masarowici Mur.; 5 - Med. conjungens Mur.; 6 - Med. inclarum Mur.; 7 - Gonolkites validus Wetz.; 8 - G. convergens (Buck.); 9 -Rarecostites mutabilis (Nic.); 10 - Parkinsonia aff. balakhanensis Khud.; 11 - Oraniceras fretensis Wetz;. 12 - Parkinsonia sp.; цифры означают: числитель - номер скважины; знаменатель - номер образца (обозначение А, Б, В см. на рис. 2)

Таблица 2

Статистическая оценка распределения видов аммонитов в караулинской и жирновской свитах, вскрытых скважинами на севере Доно-Медведицких дислокаций, \% от общего количества

\begin{tabular}{|l|c|c|c|c|}
\hline \multirow{2}{*}{ Виды аммонитов } & \multicolumn{2}{|c|}{ Караулинская (86) } & \multicolumn{2}{c|}{ Жирновская (41) } \\
\cline { 2 - 5 } & Количество & $\%$ & Количество & $\%$ \\
\hline Pseudocosmoceras michalskii (Bor.) & 27 & 32 & - & - \\
Pseudocosmoceras medium Mur. & 1 & 1 & 1 & 2 \\
Pseudocosmoceras minor Mur. & 16 & 19 & 3 & 8 \\
\hline Medvediceras masarowici Mur. & 30 & 35 & 2 & 5 \\
Medvediceras inclarum Mur. & 1 & 1 & - & - \\
Medvediceras conjungens Mur. & 1 & 1 & - & - \\
\hline Rarecostites mutabilis (Nic.) & 1 & 1 & - & 2 \\
Rarecostites harmonulatus (?) (Khud.)* & - & - & 1 & 30 \\
\hline Parkinsonia sp. & 4 & 5 & 12 & 2 \\
Parkinsonia balakhanensis Khud. & - & - & 1 & 2 \\
Parkinsonia pseudoparkinsoni Wetz. & - & - & 2 & 2 \\
Oraniceras fretensis (Wetz.) & - & - & 1 & 27 \\
\hline Gonolkites validus Wetz. & 5 & 5 & 11 & 5 \\
Gonolkites convergens (Buck.) & - & - & 4 & 2 \\
Gonolkites pseudoferrugineus (Nic.) & - & - & 1 & 2 \\
\hline <Perisphinctes> defrancei (Orb.) * & - & - & 10 \\
\hline
\end{tabular}

Примечание. Систематическое положение вида со звёздочкой, согласно Н.В. Безносову и В.В. Митте [11], установлено неоднозначно; в скобках указано количество проб.

распределения позволяет заключить: 1) одни и те же виды встречаются как в алевритовой, так и в глинистой пачках, подчёркивая их родство;
2) наибольшая частота встречаемости свойственна видам M. doneziana (Bor.) и M. echinata (Smith.), при этом первые образуют мощные ракушняковые 
банки (до 50 экз.), тогда как вторые наблюдаются чаще в виде единичных раковин; 3) несмотря на транзитный характер большинства двустворчатых моллюсков в караулинской и жирновской свитах, можно выделить комплекс, специфический только для первой, состоящий из видов Nucula aff. sana Bor., N. nana Bor., Pleuromya tenuistriata (Gold.). P. cauduta Terq., Oxytoma scarburgense Roll., Questedia aff. laevigata (Phill.), Mytiloides quenstedti Pcel., M. amygdaloides (Gold.), Inoceramus ussuriensis Vor.; 4) брюхоногие моллюски по сравнению с жирновской свитой относительно редки, а род Promathilda и вид Posidonia buchi Roem. полностью отсутствуют, но они часто встречаются в жирновских глинах. Так же редко фиксируются белемниты.

Как отмечалось выше, фораминиферы являются диагностическими фоссилиями для установления караулинской свиты, для которой принят региональный комплекс Am. subjurassicus - Lenticulina saratovensis [7]. В изученных разрезах постоянно обнаруживаются в значительных количествах виды-индексы. Так же часто присутствуют L. clara Chab., L. compacta Chab., описанные T.Н. Хабаровой в обнажениях Каменных оврагов [4]. Более редко отмечаются Haplophragmoides planus Ant., Eoguttulina triloba (Terq.), Planularia instabilis (Terq.), P. cordiformis (Terq.), P. arietis (Issler), P. ex gr. protracta (Born.), Trochamminia sp., а в виде единичных экземплярах установлены характерные для жирновской свиты виды L. volganica (Dain). Важно отметить исчезновение видов-индексов на границе с последним подразделением, тогда как они постоянно встречаются в караулинских алевритах и глинах. При этом смена комплексов в обеих свитах наблюдается в узком промежутке разреза (1-5 м).

Остракоды присутствуют в образцах довольно часто, но их разнообразие ограничено. Встречаются формы Procytheridea bajociensis (Chab.), Pr. praerimosa (Chab.), Pr. concinna Perm., Pr. pseudocrassa (Wien.), Glyptocythere aspera (Chab.), Paracypris bajocina Bate, Paracytheridea tricostata Chab., отнесённые Т.Н. Хабаровой [4] к фораминиферовой зоне Am. subjurassicus L. saratovensis.

По палинологическим данным существуют большие трудности ярусного расчленения среднеюрских отложений в связи с однотипным развитием растительности, особенно в течение байос-батского диапазона. Тем не менее следует отметить ряд признаков. Среди спор в караулинском комплексе доминируют Leiotriletes (типа Coniopteris) в количестве 20-35\% (в среднем 26,4\%). Меньшую роль играют споры Cyathidites (в среднем 9,9\%) и пыльца хвойных Pinaceae Podocarpacea (в среднем 8,6\%). Присутствуют споры Dictyophyllum (1-3\%) и плауновых (1-3\%). Среди последних установлены виды Lycopodiumsporites subrotundus (K.-M.) Vin., L. perplicatus (Bolch.) Vin., Selaginella granata Bolch., Neorais- trickia rotundiformis (K.- М.) Taras., характерные для байоса. Встречены такие споры семейства Osmundaceae (1-2\%), рода Eboracia (2\%), мхов Stereisporites compactus (Bolch.) Iljina и папоротников Klukisporites variegates Couper, Cingulatisporites pseudoalveolatus Couper, Tripartina variabilis Mal., Hymenozonotriletes utrier (Mal.) Sem. По сравнению с гнилушкинским палинокомплексом в караулинских отложениях в 2-3 раза возрастает количество спор Gleicheniaceae, Cyathidites, Leiotriletes и пыльцы Classopollis, убывают в 1,5-2 раза содержание спор диоптериевых, матониевых и ликоподиевых и количество пыльцы. Общее видовое разнообразие в караулинском комплексе существенно беднее по сравнению с гнилушкинским, что, очевидно, связано с уменьшением площади континентальной суши. Отличия караулинских и жирновских комплексов не очень заметны, качественные и количественные показатели близки. Поэтому трудно обосновать разделение данных свит по спорово-пыльцевым спектрам.

Анализ представленных сведений позволяет установить следующие диагностические признаки караулинской свиты Нижнего Поволжья, тем более что приводятся новые материалы.

1. В отличие от мнения В.И. Левиной и Н.П. Прохоровой в данной статье обосновывается самостоятельность караулинской свиты, присутствующей не только в бассейне Иловли, но и в пределах Доно-Медведицких дислокаций, т.е. на всей стратотипической местности. Она обладает двучленным строением с выделением нижней алевритовой и верхней глинистой пачек. При этом от подошвы к кровле постепенно убывает гранулометрическая дифференцированность пород.

2. В низах и верхах свиты залегают известняки характерного состава и текстуры, которые являются маркерами границ. Кроме того, в подошве наблюдаются косослоистые алевропесчаники, а подошвенные алевриты содержат неопределимый детрит моллюсков.

3. Одна и та же фауна и флора присутствует в обеих литологических пачках, что свидетельствует об их родстве. Наиболее свойственными аммонитами являются представители родов Pseudocosmoceras, Medvediceras, Rarecostites, из которых только некоторые виды проникают в жирновские глины. Нигде не обнаружены аммониты рода Garantiana, характерные для бахтемирской свиты. Несмотря на транзитный характер многих видов двустворчатых моллюсков, для караулинских отложений установлен специфический комплекс, а состав брюхоногих моллюсков является обеднённым с отсутствием видов, типичных для жирновской свиты. Фораминиферовый комплекс совпадает по видам-индексам с региональной фораминиферовой зоной.

4. Судя по наличию аммонитов, караулинскую свиту следует сопоставлять с частью аммонитовой зоны стандарта P. parkinsoni - с подзонами 
bomfordi и densicosta. Тем самым устанавливается стратиграфическое положение типового аммонита Ps. michalskii (Bor.), чему посвящены работы Н.В. Безносова и В.В. Митты [11-13], а также наша статья [26].

5. Условия залегания отложений, особенности их вещественного состава и присутствие морской фауны позволяют относить их к прибрежноморской фации, знаменующей начальную новую стадию развития морского бассейна.

6. Ареал караулинской свиты протягивается от кряжа Карпинского, где мощность достигает 40 м с увеличением роли глин, до северной оконечности Приволжской возвышенности, где она снижается до 10 м, и в составе увеличивается доля алевритов и глинистых песков.

7. Учитывая отсутствие в литературе полных разрезов караулинских отложений, предлагается использовать в качестве стратотипических разрезы в скважинах (в скобках указаны интервалы глубин): 3 (234-243 м), 9 (125-133,5 м), 15 (85-95 м), 16 (105,5-116 м), 27 (373-385 м), 35 (57-70,5 м), $114(68-81 \mathrm{~m}), 116(60-73 \mathrm{M}), 121$ (23-36 м), 149 (65-74 м), которые хорошо охарактеризованы по литологическим и палеонтологическим признакам.

Жирновская свита $\mathbf{J}_{2} \mathbf{z r}$ в качестве самостоятельного стратона была выделена В.И. Левиной на основе краткого описания разреза в Малом Каменном овраге [8]. За типовой разрез также была принята последовательность пород в интервале 48-134 м скв. 9, пробуренной в стратотипической местности. При этом в работе [8] в объём свиты были включены все глины без учёта палеонтологического обоснования их возраста. В результате такой процедуры в составе свиты оказались как глины с аммонитом $G$. convergens (Bисk.) нижнего бата, так и глины с видом Ps. michalskii (Bor.), характерным для верхнего байоса. Поэтому В.И. Левина предлагала возраст жирновской свиты в диапазоне от позднего байоса до раннего бата. При таком подходе караулинская свита не выделялась на севере Волгоградской области, что противоречит ранее известным и новым нашим фактическим материалам. Не вполне понятна приводимая палеонтологическая характеристика, в которой отсутствуют данные Е.А. Троицкой по обнажениям Каменных оврагов и наши сведения, полученные при изучении керна, вследствие чего интервалы глубин в скв. 9 даны ошибочные. Критика изложенных представлений приводится в статье [18]. Все это предопределило необходимость пересмотра мнения В.И. Левиной по жирновской свите.

Строение свиты по кернам ряда скважин иллюстрирует рис. 4. В той или иной степени оно подтверждается при обследовании разрезов в обнажениях, хотя там наблюдаются только отдельные фрагменты и границы свиты достоверно не фиксируются. Повсеместно жирновские отложения залегают на караулинских глинах. В основании первые породы обогащаются алевритовым компонентом (см. табл. 1), но в целом они согласно залегают на караулинской свите. Присутствие алевритовой примеси объясняется, очевидно, расширением морского бассейна, в результате чего возрастал привнос разнообразного терригенного материала. Литологический состав свиты по разрезу меняется незначительно - везде присутствуют алевритистые и аргиллитоподобные глины (см. табл. 1), редко отмечаются прослои алевритовых глин мощностью до 2 м без чётко выраженных границ. Все породы имеют тёмносерый цвет, рассеянный карбонат не установлен. В них наблюдается линзовидная слоистость, обусловленная неравномерным распределением алевритового материала в глинистой матрице. Среди глинистых минералов преобладают гидрослюды и каолинит, причём содержание последнего убывает по сравнению с караулинскими глинами. Специфической особенностью литологического состава является присутствие известняковых конкреций, минеральный состав которых рассмотрен в статье [27]. Можно отметить три уровня их развития. Вблизи подошвы наблюдаются известняки с текстурой конус в конус. На расстоянии 10-15 м от подошвы они интенсивно сидеритизируются. Выше по разрезу установлены алевроглинистые известняки с массивной текстурой. Мощность свиты составляет 76-84 м.

Распределение видов аммонитов показано на рис. 5. Выявляются следующие особенности: 1) присутствие тех же самых видов, которые встречены в караулинских глинах, - Ps. minor Mur., Ps. medium Mur., Med. masarowici Mur., G. validus Wetz., причём первые три формы приурочены к нижним 10 м жирновской свиты, а последняя распределена по всему разрезу; 2) существенно увеличивается количество и разнообразие представителей рода Parkinsonia; 3) наиболее интересно положение аммонитов рода Gonolkites. Из них важным в разграничении караулинской и жирновской свит является вид G. convergens (Buck.), расположенный в нижней части последнего стратона, но он не переходит в караулинское подразделение, где заканчивает свое развитие вид Ps. michalskii (Bor.); 4) кроме характерного для нижнего бата вида $G$. convergens (Buck.) в жирновской свите присутствует много верхнебайосских форм (G. validus Wetz., G. pseudoferrugineus (Nic.), P. balakhanensis Khud., P. pseudoparkinsoni Wetz. [16]); 5) по сравнению с караулинской свитой значительно снижается число выявленных аммонитов, что хорошо видно по данным табл. 2. В ней продемонстрировано преобладание представителей родов Parkinsonia, Oraniceras и Gonolkites в жирновской свите.

Принимая во внимание сведения Е.А. Троицкой по обнажениям, можно констатировать, что для жирновской свиты характерны виды родов Parkinsonia (complanata, parkinsoni, pseudoparkinsoni, balakhanensis), Oraniceras (gyrumbilicus, 

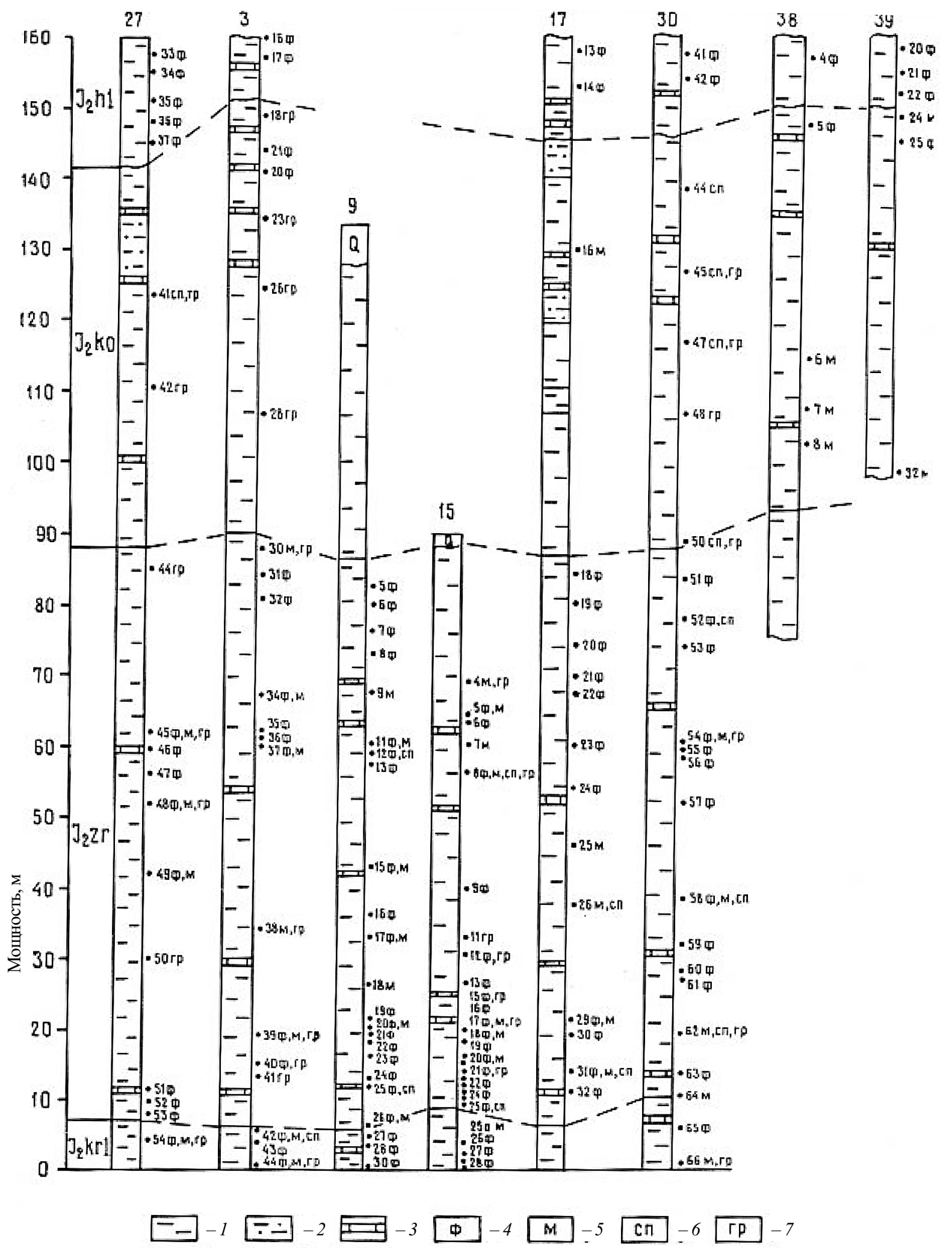

Рис. 4. Корреляция литологического состава и расположение образцов с палеонтологическим обеспечением по разрезу батских отложений в опорных скважинах; пунктиром обозначены корреляционные линии по границам подразделений (номера скважин и образцов см. на рис. 3): 1 - глины; 2 - алевриты; 3 - известняки; виды опробования; 4 - макрофауна; 5 - микрофауна; 6 - споровопыльцевые спектры; 7 - гранулометрия 


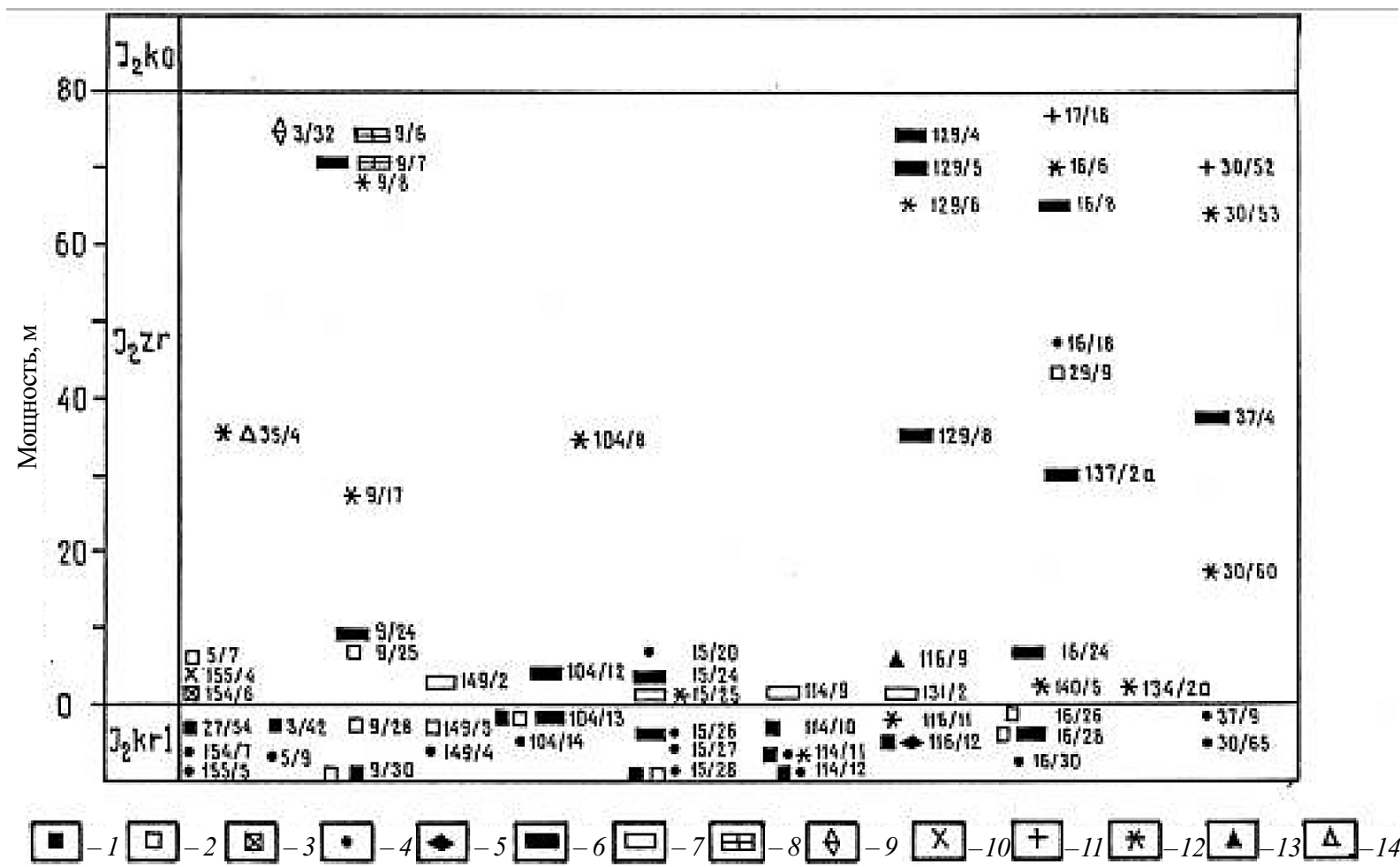

Рис. 5. Распределение видов аммонитов по усредненному разрезу жирновской свиты на севере Волгоградской области: 1 - Pseudocosmoceras michalskii (Bor.); 2 - Ps. minor Mur.; 3 - Ps. medium Mur.; 4 - Medvediceras masarowici Mur.; 5 -Rarecostites mutabilis (Nic.); 6 - Gonolkites validus Wetz.; 7 - G. convergens (Buck.); 8-G. pseudoferrugineus (Nic.); 9 - Rarecostites (?) harmonulata (Khud.); 10 - Parkinsonia balakhanensis Khud.; 11 - P. pseudoparkinsoni Wetz.; 12 - Parkinsonia sp.; 13 - Oraniceras fretensis Wetz.; 14 - Perisphinctes (?) defrancei (Orb.)

wuerttembergicus, mojarowskii, fretensis), Gonolkites (convergens, validus, pseudoferrugineus). Сюда же приникают караулинские формы Ps. medium Mur., Ps. minor Mur., Med. masarowici Mur. Heдавно B.В. Митта описал новый вид Sokurella galaczi Mit. в сокурском разрезе вблизи Саратова [28]. Такой состав сообщества намного богаче по сравнению с данными [8].

Анализ распределения двустворчатых и брюхоногих моллюсков и белемнитов по разрезу жирновской свиты позволяет сделать следующие выводы: 1) относительно караулинских отложений значительно увеличиваются встречаемость и разнообразие фоссилий. При этом можно выделить две группы. Первую составляют рода, которые наблюдаются и в караулинской свите, - Meleagrinella, Nucula, Pleuromya, Modiolus, Lima, причём первые два рода фиксируются часто, а последние три - сравнительно редко. Во вторую группу входят вновь появляющиеся рода двустворчатых моллюсков Posidonia, Platymya, Anisocardia, Corbula, Mactromya. Особо разнообразны брюхоногие моллюски родов Promathilda и Pseudomelania. Намного чаще и разнообразнее по видовому составу представлены белемниты; 2) большая часть фоссилий приурочена к нижним и средним интервалам разреза. Моллюски M. doneziana (Bor.) формируют банки, содержа- щие до 100 экз., а M. echinata (Smith.) - до 10 экз. В верхах разреза встречаются представители родов Phaenodesmia, Corbula, Anisocasrdia, a также криноидеи Pentacrisnus и черви Serpula, свидетельствующие о мелководном морском бассейне; 3 ) следует привести список окаменелостей: двустворчатые моллюски $M$. doneziana (Bor.), M. echinata (Smith.), Nucula eudorae (Orb.), N. eudorae var. acuta Bor., N. subovalis Gold., N. cf. circuliformis Bor., N. variabilis Sow., N. maga Bor., Pleuromya beanii (Mor.), Pl. ex gr. elongata (Gold.), Pl. cf. alduini (Br.), Lima duplicate Sow., Posidonia bucki Roem., Modiolus cf. gubbosa (Sow.), Anisocardia minima Sow., Mactromya varicosum (Soe), Corbula involuta Gold., Phaenodesmia ex gr. dorogomilovensis Bor., Cardinia aff. turcestanica Tscher., Platymya minuta Aq., Liostrea cf. acuminata (Gold.), Parallelodon cf. elongatum (Sow.); брюхоногие моллюски Promathilda parentismanifeata Jamp., Pr. cf. tricostata Jamp., Pr. sulcata Jamp., Pr. bicarinata pilosa Jamp., Pr. alveata Jamp., Anoptychia multifaria Jamp., An. sublata Jamp., Zygopleura cyclica Jamp., Z. confragosa Jamp., Natica tracta Piet., Pseudomelania dentata Jamp; белемниты Megateuthis cf. elliptica (Mil.), M. cf. linga (Vol.), Hobolites cf. fusiformis (Park.), Holcobelus tschegemensis (Krim.), Cylindroteuthis (C.) cf. spathi Sak. 
Стратиграфическая информативность фораминифер является высокой. Особенно важную роль они играют при изучении керна скважин, когда обнаружение остатков аммонитов ограничено диаметром и количеством поднятого керна. Именно комплексы этих микрофоссилий дают возможность значительно сузить интервал перехода от одного стратона к другому, когда одни виды исчезают из разреза, а другие появляются. При этом ключевое значение имеет совмещение образцов с аммонитами и фораминиферами, что позволяет привязать комплексы микрофауны к аммонитовой шкале.

Для жирновской свиты свойственен комплекс с устойчивым видовым составом: Lenticulina volganica (Dain), L. mironovi (Dain), Vaginulina dainae (Kos.), Astacolus bicostatus (Deec.), представители которого присутствуют в больших количествах (свыше 20 экз.) во всех изученных образцах. Кроме того, установлены следующие сопутствующие виды (в скобках указаны номеpa образцов, см. рис. 4): Darbyella kutsevi Dain (3/34, 9/9, 9/11, 15/8), Geinitzinita spatulata (Terq.) (15/9), G. nodosaria (Terq.), Lenticulina clara Chab., Planularia instabilis (Terq.), Pl. insueta Tur. (16/7), Pl. cordiformis (Terq.) (15/4), Astacolus sarpiensis Star. (16/7), Spirophtalmidium clarum Ant. (15/15). Транзитными из караулинской свиты являются виды в единичных экземплярах: L. clara Chab., Pl. instabilis (Terq.), Pl. cordiformis (Terq.). Смена комплексов фораминифер происходит достаточно быстро - на протяжении первых метров разреза, что позволяет надёжно проводить границу между караулинской и жирновской свитами [26]. Совмещение с аммонитами дает возможность указанный комплекс L. volganica - V. dainae относить по возрасту к раннему бату, а не говорить о частичной замещаемости этим сообществом караулинского комплекса Am. subjurassicus - L. saratovensis [7].

Остракоды встречаются намного реже фораминифер, и их значимость при расчленении отложений снижена ввиду их широкого стратиграфического диапазона. По всему разрезу обнаружены следующие виды: Procytheridea bajociensis (Chab.), Pr. concinna Perm., Pr. praerimosa Chab., Paracypris bajociana Bate, которые установлены и в караулинских образованиях. Но в жирновской свите дополнительно отмечены следующие виды (в скобках номера образцов): Furbegiella kiziekaspanensis (Mand.) (3/34, 9/20, 16/7), Palaeocytheridea bakirovi Mand., P. cf. priva Perm. (15/17, 15/18), P. tricostata (Chab.), P. aspera Chab. (16/5), P. tuberosa (Chab.), Macrodentina strigata (Chab.), Glyptocythere multa Perm. (3/34), Gl. aspera (Chab.), Gl. fuscils Br. (3/39).

По палинологическим данным, жирновская свита плохо отделяется от караулинских отложений по качественным и количественным показателям. Основной фон спектров составляют споры папоротников и папоротникобразных Leiotriletes, а также споры Cyathidites и Gle- ichenaceae и др. Пыльцевую часть спектров представляют хвойные с дифференцированными воздушными мешками семейств Pinaceae и Podocarpaceae $(18,6 \%)$ и гинкговые $(3,9 \%)$. Следует заметить, что спорово-пыльцевые данные, приводимые В.В. Миттой с коллегами [13] для сокурского разреза, имеют существенные отличия, которые пока что не находят своего объяснения, хотя основную долю спектров составляют споры папоротников.

Таким образом, изложенные сведения в совокупности с ранее известными фактами позволяют отметить следующие особенности жирновской свиты.

1. Свита имеет устойчивый литологический состав, в котором доминируют глины мощностью порядка 80 м. Лишь в подошвенной части в них наблюдается примесь алевритовой фракции. От караулинской свиты жирновские отложения отделяются частыми конкрециями известняков с текстурой конус в конус. Верхняя граница с каменноовраженной свитой литологически не выражена, но чётко фиксируется по цвету пород (см. ниже).

2. Для жирновской свиты свойственны аммониты родов Parkinsonia (4 вида), Oraniceras (4 вида), Gonolkites (3 вида), встречаются переходные из нижележащих отложений некоторые виды родов Pseudocosmoceras, Medvediceras. Существенно возрастает количество и разнообразие двустворчатых и брюхоногих моллюсков, а также белемнитов. Для свиты характерным является фораминиферовый комплекс L. volganica - V. dainae, виды-индексы которого не установлены в караулинской свите. Эти данные дают основание для датирования жирновской свиты только ранним батом в отличие от позднебайосско-раннебатского возраста, принятого в [8].

3. Условия залегания отложений, особенности их вещественного состава и присутствие морской фауны позволяют относить их к осадкам открытого эпиконтинентального морского бассейна, которые свидетельствуют об его расширении по сравнению с караулинским временем.

4. Ареал жирновской свиты охватывает площадь от кряжа Карпинского до окончания Приволжской возвышенности, при этом на юге мощность достигает $100 \mathrm{M}$, а на севере убывает до 30-40 м, и здесь возрастает роль алевритовой составляющей.

5. Принятый в [8] стратиграфический разрез в Малом Каменном овраге является неполным, а в описании отсутствуют многие виды аммонитов, но зато в объём включены заведомо караулинские глины. Поэтому в качестве гипостратотипа предлагаются разрезы по скважинам (в скобках интервалы глубин) 3 (150-234 м), 9 (43-125 м), 15 (2,5-85 м), 17 (154-233 м), 27 (292-373 м), 30 (225-303 м), где наблюдаются нижняя и верхняя границы и породы обладают хорошими литологической и палеонтологической характеристиками. 
Следует отметить дополнительные скважины, в кернах которых получены данные по аммонитам и фораминиферам, по которым обосновывается разделение жирновской и караулинской свит: 129 (46-142 м), 131 (14-22 м), 114 (0,5-68 м), 104 (0,5-66 м), 149 (3,5-65 м).

Каменноовражная свита $\mathbf{J}_{2} \mathbf{k o}$ выделена В.И. Левиной и Н.П. Прохоровой [8] в объёме среднего и верхнего бата со стратотипическим разрезом в Малом Каменном овраге (вблизи Жирновска). По их мнению, она представлена серыми алевролитами с прослоями тёмно-серых глин и известняковых песчаников с общей мощностью 20 м. Возраст принимается на основании находок фораминифер Ammodiscus baticus Dain, двустворок Meleagrinella и диноцист Kalyptea dinoceras без указания места отбора образцов.

Наши данные по опробованию керна ряда скважин и описанию стратотипического разреза не согласуются с этими представлениями ни по литологии и мощностям, ни по палеонтологическому обеспечению возраста. Корреляция литологического состава в ряде скважин и размещение отобранных образцов демонстрируются на рис. 4. Изученные отложения залегают согласно на жирновских тёмно-серых глинах. В их подошве наблюдается алевритовая примесь (до 8\%). В целом свита сложена довольно однородными светло- и голубовато-серыми алевритистыми неизвестковистыми глинами с прослоями алевритовых глин и алевритов без чётко выраженных границ (см. табл. 1). Постоянно фиксируется тонкая горизонтальная слоистость, прослеживаемая по всему разрезу. Она создана чередованием тёмного глинистого и более светлого алевритового материала. Соотношение глин и алевритов для полного разреза оценивается как $80: 20$, но в верхах оно достигает величины 50 : 50 за счёт увеличения количества алевритовых прослоев. Верхняя граница свиты совпадает с перерывом седиментации, когда опесчаненные хлебновские глины $\mathrm{J}_{2} \mathrm{hl}$ нижнего келловея, содержащие характерную фауну аммонитов и фораминифер, налегают на светло-серые каменноовражные глины с фораминиферами Am. baticus Dain. Мощность свиты изменяется в пределах 54-61 м, что согласуется с ранними результатами [1, 4-6, 21, 25].

Эти признаки - светлая окраска и тонкая слоистость пород - являются диагностическими, позволяющими отличать их от тёмноокрашенных глин келловея или нижнего бата даже в полевых условиях. Кроме того, по разрезу наблюдаются линзовидные прослои тёмно-серых массивных известняков с различным количеством терригенной составляющей [27]. Для них характерна постоянно проявленная сидеритизация карбонатного и глинистого вещества, а также пологоволнистая и мульдообразная слоистость. Эти признаки свойственны только известнякам каменноовражной свиты.
Органическими остатками отложения довольно бедны. В некоторых образцах обнаружены раковины Ostrea sp. $(38 / 5,39 / 25)$, Posidonia buchi Roem. (3/21) и чешуйки рыб (3/20), приуроченные к кровле разреза. Указания В.И. Левиной и Н.П. Прохоровой о присутствии двустворок Meleagrinella на изученной площади не подтвердились. Если рассматривать распределение этих моллюсков по вертикальному разрезу жирновской и каменноовражной свит в конкретных скважинах (рис. 4), то можно заметить существенное уменьшение частоты их встречаемости уже в верхах первого стратона, что свидетельствует об ухудшении условий их обитания.

Более обычны находки фораминифер Am. baticus Dain (38/6, 39/24, 129/1), обнаруженных по всей протяжённости разреза и иногда встречающихся в значительных количествах, особенно там, где не наблюдаются карбонатные конкреции. В отобранных 46 образцах (через каждые 10 м разреза) в кернах ряда скважин микрофауна не обнаружена. Так же пустыми оказались образцы, взятые в обнажении Малого Каменного оврага. Все это свидетельствует о низкой встречаемости фораминифер в породах.

Комплекс остракод представлен видами Procytheridea praerimosa (Chab.) (38/7), Pr. bajociensis (Chab.) (17/16, 38/8, 39/24, 39/32) и Paracypris bajocianna Bate $(38 / 8,38 / 7)$, зафиксированными и в жирновских образованиях. В одном образце (39/32) отмечен вид Protocythere clivosa (Chab.), свойственный, по мнению Т.Н. Хабаровой, среднему бату. Палинологическая характеристика каменноовражной свиты практически от отличается от таковой в жирновских отложениях.

По представлениям В.И. Левиной и Н.П. Прохоровой, в объём каменноовражной свиты включен и верхний бат. Для стратотипической местности - север Доно-Медведицких дислокаций - это ничем не доказывается. Присутствие диноцисты Kalyptea dinoceras в разрезе Малинового оврага (Саратовская область) не может быть свидетельством присутствия верхнего бата в рассматриваемом районе, и перенос этих данных далеко на юг (на 130 км) вряд ли можно признать правомерным, особенно для стратотипического разреза.

Находки Kalyptea dinoceras на Печорском Севере совмещаются с аммонитом Cadoceras variabile Spath, который C.В. Меледина с коллегами $[29,30]$ помещает вблизи кровли верхнего бата. Для Саратовско-Волгоградского Правобережья [9] слои с Kalyptea dinoceras принадлежат низам келловея, а пески и глины с Dichadogonyaulax sellwodii - Protobatioladinium sp. - к верхнему бату. Правда, А.Г. Олферьев [10] отметил ошибочность этих данных по диноцистам. В Подмосковье последняя ассоциация встречена в средней части мокшинской свиты ранне-среднебатского возраста, но вблизи её кровли установлены $\mathrm{Ka}$ lyptea dinoceras. Следовательно, вопрос не может считаться решённым. Поэтому вносить данную 
находку в стратотипический разрез свиты вряд ли можно.

Само присутствие такой эндемичной фораминиферы, как Am. baticus Dain, указывает на развитие неблагоприятных условий обитания морских организмов, прежде всего по солености. Реконструкции И.Г. Сазоновой и Н.Т. Сазонова [25] свидетельствуют об обособленности морского бассейна и его опреснении в течение среднего бата. Об этом же говорят находки моллюска Ostrea $\mathrm{sp}$. Неодновременное исчезновение фауны в жирновских отложениях (см. рис. 4) можно трактовать как пространственную неоднородность такового опреснения даже в пределах ограниченной площади. Поэтому больше оснований полагать здесь завершение позднебайосско-среднебатской седиментации, чем её продолжение в позднем бате. Тем более что фораминиферы Am. baticus Dain соотносятся с аммонитом Procerites progracilis (Cox et Ark.) [7] начальной одноимённой зоны аммонитового стандарта [16]. Таким образом, целесообразнее принять возраст каменноовражной свиты только среднебатским.

Изложенные материалы и соображения по каменноовражной свите совместно с анализом опубликованных данных позволяют сделать следующие выводы.

1. В отличие от представлений В.И. Левиной и Н.П. Прохоровой в статье [8] обосновывается мнение о сравнительно однородном литологическом составе подразделения, сложенного преимущественно серыми глинами с прослоями алевритов и известняков, при этом к верхам разреза увеличивается доля алевритов. Мощность отложений варьирует вокруг величины 60 м. Эти данные согласуются с результатами предшествующих исследований. Нижняя граница с жирновской свитой выражена нечётко, а верхняя совпадает с перерывом осадкообразования, выше которого развиты келловейские глины.

2. В каменноовражных породах встречено мало органических остатков. Наиболее обычны фораминиферы Am. baticus Dain, которые соотносятся с аммонитовой зоной progracilis стандарта, начинающей средний бат. Находка диноцисты Kalyptea dinoceras, к тому же обнаруженной на севере от стратотипического разреза, не может служить основанием для расширения возраста свиты до позднего бата.

3. Условия залегания отложений, их вещественный состав и бедность морской фауны свидетельствуют о регрессивном характере свиты, которая отражает завершение верхнебайосскосреднебатского осадконакопления на территории Нижнего Поволжья.

4. Ареал каменноовражной свиты охватывает большую площадь региона, где её мощность составляет порядка 60 м, но к северу величины убывают с одновременным возрастанием доли алевритов. На самом юге региона (кряж Карпинского) среднебатские отложения не установлены.
5. Учитывая неполноту стратотипического разреза в Малом Каменном овраге и отсутствие находок фауны, предлагается в качестве гипостратотипа принять разрезы в скважинах, расположенных в стратотипической местности (в скобках интервалы глубин): 3 (89-150 м), 17 (94-154 м), 27 (238-2392 м), 30 (167-225 м), 38 (40-97 м), 39 (14,5-93,5 м), 129 (2-46 м).

\section{Заключение}

Выполненный анализ литологических и палеонтологических сведений, полученных при детальном опробовании непрерывных разрезов морских байос-батских отложений в кернах многих скважин в стратотипической местности при совмещении находок аммонитов и фораминифер, позволяет внести необходимые коррективы в существующую стратиграфическую схему средней юры Нижнего Поволжья $[8,9]$. Верхнюю часть разреза составляют последовательно наращивающиеся три свиты, характеризующие позднебайосско-среднебатскую стадию геологической истории региона. Кроме того, уточняется объём и частично возраст бахтемирской и впервые выделяемой родионовской свит, венчающих раннюю стадию морской седиментации. Последние развиты только до широты Камышина, тогда как первые три стратона распространены на большой площади Нижнего Поволжья и составляют новый этап трансгрессивного развития региона. Отмечается снижение мощностей подразделений и увеличение доли алевритового компонента в северном направлении - в пределах СаратовскоУльяновского Правобережья.

Внесенные коррективы кратко можно свести к следующим положениям.

1. Родионовская свита должна соотноситься с аммонитовой зоной Strenoceras niortense стандарта и имеет прибрежно-лагунное происхождение, согласно предложению А.И. Сарычевой [5].

2. Бахтемирская свита соответствует нижней половине аммонитовой зоны G. garantiana стандарта - подзонам dichotoma и subgaranti и отвечает осадкам открытого моря.

3. Караулинская свита соотносится с верхами зоны P. parkinsoni стандарта - с подзонами densicosta и bomfordi согласно представлениям В.В. Митты [12, 13]. Она принадлежит к прибрежно-морской фации новой стадии развития трансгрессии.

4. Жирновскую свиту предлагается ограничить большей частью аммонитовой зоны zigzag стандарта - подзонами convergens и macrescens по международной шкале или зоной besnosovi для Русской плиты, по В.В. Митте [12, 13]. Она характеризует условия седиментации в открытом морском бассейне.

5. Каменноовражная свита имеет только среднебатский возраст. Присутствующие фораминиферы 
Am. baticus Dain сопоставляются с аммонитовой зоной progracilis стандарта. Она относится к регрессивной фации морского бассейна.

Такие стратиграфические объёмы местных стратонов отображены в табл. 3. Представленные материалы показывают целесообразность применения комплексных характеристик при выделении свит. В соответствии с положениями Стратиграфического кодекса [31] они включают следующие признаки: литологическую и палеонтологическую характеристики, имеющие равноценное значение; фациальную принадлежность; мощность и амплитуду их колебаний по изученной площади; соотношение с подстилающими и покрывающими образованиями с описанием контактовых зон между стратонами; корреляцию с известными стратотипами; также учитывается географическое распространение подразделения. Такой подход отличается от литостратиграфического расчленения, используемого В.И. Левиной и Н.Р. Прохоровой. Он является более обоснованным при выделении и описании местных подразделений и позволяет выявлять детали геологической истории региона.

Таблица 3

Варианты толкования стандартной аммонитовой шкалы батского яруса, предлагаемые схемы расчленения бата на Печорском Севере $[29,30]$ и в Поволжье $[12,13]$ и соотношение с ними изученных караулинской, жирновской и каменноовражной свит на севере Волгоградской области

\begin{tabular}{|c|c|c|c|c|c|c|c|c|}
\hline \multirow[b]{2}{*}{ 充 } & \multirow[b]{2}{*}{ 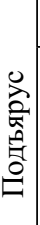 } & \multicolumn{2}{|c|}{ С.В. Меледина и др. $[29,30]$} & \multicolumn{4}{|c|}{ В.В. Митта $[12,13]$} & \multirow[b]{2}{*}{$\begin{array}{l}\text { Свиты на се- } \\
\text { вере } \\
\text { Волгоградской } \\
\text { области }\end{array}$} \\
\hline & & $\begin{array}{c}\text { Стандартная зо- } \\
\text { нальная шкала } \\
\text { Европы [16] }\end{array}$ & $\begin{array}{c}\text { Печорский Север } \\
\text { России }\end{array}$ & 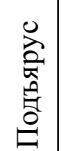 & $\begin{array}{c}\text { Стандартная } \\
\text { шкала }\end{array}$ & \multicolumn{2}{|c|}{$\begin{array}{c}\text { Русская платформа } \\
\text { (бассейн Волги) }\end{array}$} & \\
\hline \multirow{13}{*}{ 啮 } & \multirow{6}{*}{ 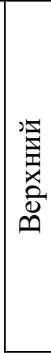 } & \multirow{2}{*}{$\begin{array}{l}\text { Clydoniceras } \\
\text { discus }\end{array}$} & \multirow{2}{*}{$\begin{array}{c}\text { Слои с Cadoceras } \\
\text { variabile }\end{array}$} & \multirow{6}{*}{ 状 } & discus & \multicolumn{2}{|c|}{ Cadoceras aff.calyx } & \multirow{8}{*}{ Размыв } \\
\hline & & & & & hollandi & \multirow{4}{*}{\multicolumn{2}{|c|}{$\begin{array}{l}K . \text { aff.peramplus } \\
\text { Kepplerites sp. }\end{array}$}} & \\
\hline & & \multirow{3}{*}{ Oxycerites orbis } & \multirow{3}{*}{$\begin{array}{c}\text { Аммониты не } \\
\text { найдены }\end{array}$} & & & & & \\
\hline & & & & & & & & \\
\hline & & & & & blanazense & & & \\
\hline & & Procerites hodsoni & \multirow{4}{*}{$\begin{array}{l}\text { Слои с Arctico- } \\
\text { ceras ishmae и } \\
\text { A. harlandi }\end{array}$} & & hodsoni & \multirow{2}{*}{\multicolumn{2}{|c|}{$\begin{array}{l}\text { Cardiociratidae gen. } \\
\text { et sp. }\end{array}$}} & \\
\hline & \multirow{4}{*}{ 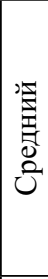 } & \multirow{2}{*}{$\begin{array}{c}\text { Tulites } \\
\text { subcontractus }\end{array}$} & & \multirow{3}{*}{ 恣 } & morrisi & & & \\
\hline & & & & & subcontractus & \multirow{2}{*}{\multicolumn{2}{|c|}{ Аммониты не найдены }} & \\
\hline & & Procerites progra- & & & progracilis & & & \multirow{2}{*}{$\begin{array}{c}\text { Каменноовраж- } \\
\text { ная } \mathrm{J}_{2} \text { kо } \\
\text { (аммониты не } \\
\text { найдены) }\end{array}$} \\
\hline & & $\begin{array}{l}\text { Asphinctes tenui- } \\
\text { plicatus }\end{array}$ & $\begin{array}{c}\text { Аммониты не } \\
\text { найдены } \\
\end{array}$ & \multirow{4}{*}{ 突 } & tenuiplicatus & ishmae & ishmae & \\
\hline & \multirow{3}{*}{ 罯 } & \multirow{3}{*}{$\begin{array}{l}\text { Zigzagiceras zig- } \\
\text { zag }\end{array}$} & \multirow{3}{*}{$\begin{array}{c}\text { Слои с Oraniceras } \\
\text { cf. gyrumbilicum, } \\
\text { Golonkites cf. con- } \\
\text { vergens }\end{array}$} & & yeovilensis & harlandi & & \\
\hline & & & & & macrescens & besnosovi & & \\
\hline & & & & & convergens & $\begin{array}{l}\text { mo- } \\
\text { jarowskii }\end{array}$ & $\begin{array}{l}\text { besnos- } \\
\text { ovi }\end{array}$ & $\begin{array}{c}\text { Жирновская } \\
\mathrm{J}_{2} \mathrm{zr}\end{array}$ \\
\hline \multirow{2}{*}{ 兽 } & \multirow{2}{*}{ 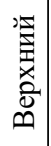 } & \multirow{2}{*}{$\begin{array}{l}\text { Parkinsonia } \\
\text { parkinsoni }\end{array}$} & & \multirow{2}{*}{ 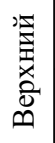 } & bomfordi & masarowici & \multirow{2}{*}{$\begin{array}{l}\text { michal- } \\
\text { skii }\end{array}$} & \multirow{2}{*}{$\begin{array}{c}\text { Караулинская } \\
\mathrm{J}_{2} \mathrm{krl}\end{array}$} \\
\hline & & & & & densicosta & & & \\
\hline
\end{tabular}

Если для родионовской, бахтемирской и караулинской свит границы с той или иной детальности являются достаточно определёнными в рамках указанных возрастных диапазонов, то для жирновской и каменноовражной свит картина другая. Это связано с разным толкованием аммонитового стандарта применительно к Русской платформе, обострённым в связи с находками аммонитов Arcticoceras harlandi и Ar. ishmae в сокурском разрезе вблизи Cаратова [13]. Указанные данные дали основания В.В. Митте с коллегами частично пересмотреть аммонитовую шкалу для Русской платформы (бассейн Волги) (см. табл. 3). Такой подход имеет отношение к установлению границ жирновской и каменноовражной свит. 
Если принять точку зрения С.В. Мелединой и др. $[29,30]$, то жирновская свита будет соответствовать полной аммонитовой зоне zigzag стандарта, а верхняя граница каменноовражной свиты должна проводиться в основании зоны subcontractus среднего бата, где также появляются суббореальные аммониты Ar. harlandi и Ar. ishmae. Если же согласиться с мнением В.В. Митты и др., то объём жирновской свиты должен быть ограничен зоной besnosovi (подзонами convergens и macrescens стандарта), а зона yeovilensis нижнего бата будет тогда соответствовать нижней части каменноовражной свиты. Вопрос пока что не может быть разрешён с надлежащей надёжностью, что связано с отсутствием многих аммонитов, принятых в международном стандарте.

Дело усложняется еще одним обстоятельством. В жирновской свите обнаружены исключительно тетические аммониты, и весь разрез байос-батских отложений характеризует полный цикл развития морской трансгрессии, направленной с юга на север. При этом выделяются две стадии этого процесса, которым соответствуют родионовская и бахтемирская свиты (в первой) и караулинская - каменноовражная свиты (во второй). В то же время всеми исследователями признается суббореальное происхождение аммонитов Ar. harlandi и Ar. ishmae. В келловее уже повсеместно распространены бореальные организмы, хотя ещё встречаются в нижнем подъярусе тетические формы. Следовательно, можно полагать, что в районе Саратова намечается граница между тетической и суббореальной палеобиогеографическими провинциями, вследствие чего в южных районах в нижнем бате присутствуют только тетические аммониты, а в северных появляются суббореальные виды. При этом граница является, очевидно, извилистой. На территории Волгоградско-Саратовского Правобережья, видимо, до конца среднего бата сохранялось влияние тетического бассейна. Отсюда каменноовражная свита отражает его постепенную регрессию в северном направлении. Но на востоке Правобережья и в Заволжье, т.е. на площади Волгоградского меридионального палеопрогиба, уже в конце раннего бата, если согласиться с данными В.В. Митты и др., суббореальное море проникало до Саратова, которое, однако, долго не сохранялось, а снова осушалось на протяжении большей части позднего бата. Постоянное его существование в Нижнем Поволжье связывается с началом келловейского века. Установление верхнебатских аммонитов в разрезе Просека в Нижегородской области [32] подтверждает такое представление. Тогда аммониты Ar. harlandi и Ar. ishmae будут соответствовать нижней части каменноовражной свиты, а аммонит Pr. progracilis - её верхней половине, что и отображено в одном из вариантов в табл. 3 . В недавней работе по аммонитовой шкале печорской юры Ю.С. Репин [33] показал, что вид Ar. harlandi относится к зоне tenuiplicatus, венчающей нижний бат, а вид $A r$. ishmae сопоставляется с зоной progracilis среднего бата, т.е. эти данные сравнимы с представлением, что каменноовражная свита укладывается в диапазон от верхов нижнего до середины среднего бата.

Таким образом, изложенная динамическая модель развития верхнебайосско-среднебатской терригенной седиментации на территории Нижнего Поволжья является намного сложнее, чем представленная статичная картина в существующей стратиграфической схеме, к тому же основанной на очень ограниченном в пространственном отношении фактическом материале. Не всё, конечно, в предложенной модели имеет достаточное обоснование. Потребуются значительные усилия для её подтверждения и уточнения, но все равно они должны быть направлены для воссоздания правдоподобной геологической истории путем обобщения и комплексирования многих приёмов исследований.

Авторы благодарны В.В. Митте, Д.Н. Киселёву, А.Г. Олферьеву и В.Б. Сельчеру за обсуждение изложенных материалов и сделанные критические замечания.

\section{Библиографический список}

1. Камышёва-Елпатьевская В.Г., Николаева В.П., Троичкая E.A. Стратиграфия юрских отложений Саратовского Правобережья по аммонитам // Тр. ВНИГРИ. 1959. Вып. 137. С. 3-265.

2. Зоны юрской системы в СССР // Тр. МСК. 1982. Т. 10. $192 \mathrm{c}$.

3. Даин Л.Г. Материалы к стратиграфии юрских отложений Саратовской области // Тр. ВНИГРИ. 1948. Нов. сер. Вып. 31. Сб. 1. С. 49-82.

4. Хабарова T.Н. Фораминиферы юрских отложений Саратовской области // Тр. ВНИГРИ. 1959. Вып. 137. C. $461-519$.

5. Сарычева А.И. Новые данные по стратиграфии юрских отложений Волгоградской области // Тр. Волгоград. НИИНГ. 1964. Вып. 3. С. 48-58.

6. Троицкая Е.А., Хабарова Т.Н. Стратиграфия средней юры Нижнего Поволжья // Юрские отложения Русской платформы. Л., 1986. С. 23-30.

7. Практическое руководство по микрофауне СССР. Т. 5. Фораминиферы мезозоя / Ред. А.Я. Азбель и А.А. Григялис. Л., 1991.375 с.

8. Левина В.И., Прохорова Н.П. Местные стратиграфические подразделения нижней и средней юры Прикаспийского региона // Недра Поволжья и Прикаспия. 2002. Вып. 29. С. 6-13.

9. Объяснительная записка к унифицированной стратиграфической схеме юрских отложений Русской платформы / Ред. М.С. Месежников. СПб., 1993. 72 с.

10. Олферьев А.Г. Юрские отложения востока Русской платфобрмы // Вопр. совершенствования стратиграфической основы фанерозойских отложений нефтегазоносных регионов России. СПб., 1997. С. 95-107.

11. Безносов Н.В., Митта В.В. Позднебайосские и бат- 
ские аммониты Северного Кавказа и Средней Азии. М., $1993.347 \mathrm{c}$.

12. Митта В.В. О проблемах биостратиграфии средней юры Европейской России // Недра Поволжья и Прикаспия. 2004. Вып. 39. С. 28-33.

13. Митта В.В., Барской И.С., Грюндель Й. и др. Верхний байос и нижний бат в окрестностях Саратова // Новости из Геол. музея им. В.И. Вернадского. 2004. № 12.39 с.

14. Мурашкин П.К. Среднеюрские аммониты северной оконечности Доно-Медведицких дислокаций // Бюл. МОИП. Отд-ние геол. 1930. Т. 8, № 1-2. С. 139-166.

15. Николаева В.П. Систематическое положение и объем рода Pseudocosmoceras // Палеонтологический журн. 1967. № 2. C. $52-61$.

16. Biostratigraphic du Jurassique Ouest Europeen et Mediterraneen. Zonation paralleles et distribution des inverte-bres et microfossiles // Bull. Centre Rech. ELF Explod. Prod. 1997. Mem. 17. 440 p.

17. Салтылков В.Ф. Состояние стратиграфической изученности среднеюрских отложений Нижнего Поволжья. Ст. 3. Изученность верхнебайосского подъяруса // Недра Поволжья и Прикаспия. 2006 а. Вып. 47. С. 24-33.

18. Салтыков В.Ф. Состояние стратиграфической изученности среднеюрских отложений Нижнего Поволжья. Ст. 4. Изученность батского яруса // Недра Поволжья и Прикаспия. 2006 б. Вып. 48. С. 8-16.

19. Сарычева А.И. Микрофаунистическая характеристика байосских и верхнеюрских отложений Бузгинского блока // Тр. ВНИГНИ. 1971. Вып. 84. С. 76-83.

20. Хабарова Т.Н. Новые фораминиферы из байоса юговостока Русской платформы // Палеонтологический журн. 1987. № 2. C. 122-124.

21. Смирнов А.В. Литология и литофация юрских отложений Волгоградского Поволжья // Тр. Волгоград. НИИНГ. 1962. Вып. 1. С. 111-129.

22. Салтыков В.Ф., Киселева О.И. Среднеюрские континентальные отложения гнилушкинской свиты Поволжья // Бюл. МОИП. Отд-ние геол. 2006. Т. 81, вып. 1. C. 16-35.
23. Панов Д.И., Шиханов С.Е., Беленев П.О. Этапы развития Русской плиты в юрском периоде и их корреляция с этапами развития Крыма и Кавказа // Бюл. МОИП. Отд-ние геол. 2005. Т. 80, вып. 1. С. 26-36.

24. Мазарович А.Н. Среднеюрские отложения реки Иловли // Вестн. Моск. горной академии. 1923. Т. 2, № 1. C. 29-60.

25. Сазонова И.Г., Сазонов Н.Т. Палеогеография Русской платформы в юрское и раннемеловое время // Тр. ВНИГНИ. 1967. Вып. 52. 260 с.

26. Салтыков В.Ф., Стариева Г.Н., Троицкая Е.А. К проблеме биостратиграфической характеристики байосбатской границы в Нижнем Поволжье // Докл. ДАН. 2005. T. 401, № 3. С. 366-369.

27. Салтыков В.Ф. Карбонатные конкреции в среднеюрском разрезе Нижнего Поволжья // Изв. Сарат. ун-та. Сер. Науки о Земле. 2008. Вып. 1. С. 64-74.

28. Мumma B.B. Sokurella galaczi gen. et. sp. nov. и другие среднеюрские Parkinsoniidae (Ammonoidea) Нижнего Поволжья // Палеонтологический журн. 2004 б. № 3. C. $30-35$.

29. Меледина С.В., Захаров В.А. Последовательность аммонитовых зон бата и келловея бассейна р. Печоры ключевая для зональной корреляции средней юры Сибири со стандартом // Геология и геофизика. 1996. Т. 37, № 2. C. 25-36.

30. Меледина С.В., Ильина В.И., Нальняева Г.И. Параллельные биостратиграфические шкалы бореального бата и келловея Печорского Севера как инструмент межрегиональных корреляций // Стратиграфия. Геол. корреляция. 1998. T. 6, № 3. С. 29-42.

31. Стратиграфический кодекс. 2-е изд., доп. СПб., 1992. 120 с.; 3-е изд. СПб., 2006. 96 с.

32. Гуляев Д.Б., Киселёв Д.Н. Бореальный морской верхний бат Среднего Поволжья (аммониты и стратиграфия) // Стратиграфия. Геол. корреляция. 1999. Т. 7, № 3. C. 79-94.

33. Репин Ю.С. Аммонитовая шкала печорской юры // Бюл. МОИП. Отд-ние геол. 2007. Т. 82, вып. 2. С. 24-31. 